Olha V. MYSECHKO,

PhD (Pedagogy), Associate Professor, The Translation Chair, Bohdan Khmelnytsky National Academy of the State Border Guard Service of Ukraine; 46, Shevcheko str., Khmelnytsky, 29001, Ukraine; tel.: +38 (0382) 704231; e-mail: nadpsu@pvu.gov.ua ; ORCID ID: 0000-0003-4667-6252

Tetiana L. SHCHEgOLEVA,

PhD (Pedagogy), Senior Lecturer, The English Language Chair, Bohdan Khmelnytsky National Academy of the State Border Guard Service of Ukraine; 46, Shevcheko str., Khmelnytsky, 29001, Ukraine; tel.: +38 (0382) 704231; e-mail: nadpsu@pvu.gov.ua ; ORCID ID: 0000-0002-3892-5426

\title{
ECO-DISCOURSE TEXTS: A SYNTACTIC PARAMETER (based on the English-language official documents of India)
}

Summary. The problematic of the article lies within eco-linguistics as the newest branch of language study. Arguing for the comprehensive parameterization of eco-discourse, including the study of ecological terminology, lexical and phraseological innovations, etc., the authors outline the purpose of the article as to define the peculiarities of syntactic organization of professional texts on ecology. The corpus of factual material includes Notifications of the Ministry of Environment and Forests of India. The object of the investigation is the syntactical characteristics of ecological texts. The necessity of the proposed research is determined by a significant role of eco-discourse in eco-education of the population of India. The findings consist in identifying specific features of the syntactic organization of eco-discourse. Stylistic heterogeneity of eco-texts has been proved; such a diversity implies usage of certain language units on different language levels, including the syntactic one. The research has made it possible to draw the conclusions that eco-discourse is a conglomerate of stylistically and structurally various texts, 'deepened in life', whose study should not be reduced to description of terminology only. Further research is seen in comprehensive inventory of ecological texts and in their typological classification.

Key words: ecolinguistics, ecological discourse, text syntax, sentence, normative legal document, the English language of India.

Статтю отримано 2.11.2018 p.

http://dx.doi.org/10.18524/2307-4558.2018.30.141903

УДК $811.163 .2 ' 366.58$

\section{СЛАВКОВА Светлана}

доктор по педагогика, доцент, катедра «Руски език и литература», Департамент за устен и писмен превод“, Болонски университет - Кампус Форли; Corso della Repubblica 136, 47121 Forlì, Italia; тел.: +39 (349) 3747948; e-mail: svetlana.slavkova@unibo.it; ORCID ID: 0000-0001-5900-6616; SCOPUS ID: 56466016; РИНЦ Autor ID: 437711

\section{КОЙ-ВЪПРОСИТЕ В БЪЛГАРСКИЯ ЕЗИК ОТ ГЛЕДНА ТОЧКА НА РЕАЛИЗАЦИЯТА В ТЯХ НА ОБЩОФАКТИЧЕСКОТО ЗНАЧЕНИЕ НА НЕСВЪРШЕНИЯ ВИД}

Анотация. Целта на настоящата статия е анализ на употребите на несвършения вид на глагола от гледна точка на общофактическото му значение. Обект на анализ са въпросите с местоимението жой в българския език. По-специално се разглеждат критериите за избор на видо-времева форма - презенс, перфект и аорист на глаголите от свършен и несвършен вид (съответно, СВ и НСВ), като се изследва влиянието на семантиката на конкретните глаголни времена върху проявата на значенията на НCB, включително и на общофактическото и на неговите подвидове. Освен това, анализирайки избора на видо-времевите форми не трябва да се подценява въпросът за ролята на номинативните категории. Резултатът от анализа показва, че общофактическое значение се проявява на ниво изказване и че освен вида на глагола важна роля играят глаголното време, референтният статус и определеността на имената. Основният извод e, че несвършеният аорист в българския език изразява акционалната разновидност на общофактическото значение на терминативни несвършени глаголи с определен пряк обект. Неопределено пряко допълнение (с нулев член) също е възможно, ако извършването на действието, за което се пита, се предполага (или очаква) от говорещия. Несвършеният перфект на глаголите с определен пряк обект също може да изразява акционалния подвид на общофактическото значение като допуска эмоционално критическо отношение към извършеното действие. И в двата случая глаголът HCB може да бъде заменен със CB. При все това, основните случаи на употреба на НСB перфект се срещат при неактуални, нелокализирани във времето ситуации, които отразяват минал опит на субекта, което на свой ред позволява те да бъдат квалифицирани като экзистенциален подтип на общофактическото значение. По тази причина прекият обект на глагола може да бъде изразен от нереферентни именни групи (с нулев член). Възможно е също така наличието на неопределеното наречие някога. В тези въпроси глаголът от НСВ не може да бъде заменен с глагол от СВ.

Ключови думи: вид на глагола, общофактическо значение, аорист, перфект. 
Поставяне на проблема. Общоприето е мнението, че въпросът с пълнозначна въпросителна дума и глагол от НСВ има за задача да изясни кои са участниците и обстоятелствата на ситуацията, докато самият фокт на осъществяване на действието (а също и на достигане на резултата) представлява пресупозиция. За разлика от руския език, въпросът за употребата на несвършения вид на глаголите в българските въпроси, оформени с помощта на пълнозначни въпросителни думи, не е разглеждан в рамките на изучаването на общофактическото значение на НСВ. Смятаме, че едно изследване на специалните въпросителни изречения с местоименната дума жой е необходимо преди всичко от гледна точка на реализацията на видо-времевите форми в тях.

Връзка с предишните изследвания. На частните значения на НСВ в руския език, сред които е и общофоктическото, са посветени много изследвания $[4 ; 9 ; 10 ; 11 ; 17 ; 18]$. Специални изследвания са посветени на референтния статус на глаголната предикация във въпросите, оформени с пълнозначна въпросителна дума $[19 ; 6 ; 13]$. Колкото до българския език, макар общофактическото значение на НСВ да се отбелязва както за формите на аориста, така и за формите на перфекта [1; 2 ; $5 ; 13]$, специални изследвания, посветени на употребата на видо-времевите форми във въпросите с пълнозначни въпросителни думи не са ни известни.

В своя детайлен анализ на въпросите с местоимението жто в руския език Х. Р. Мелиг откроява два типа глаголна предикация и съответно две групи въпроси с това местоимение. Първият тип са въпросите относно конкретни, актуализирани, присъстващи в ситуацията действия ( $R$ imo писал адрес на конверте? Забыли написать индекс $)^{1}$. Те са възможни само с пределни глаголи (accomplishments според терминологията на Вендлер), назоваващи контролируемо действие, и съответстват на (екземпляра) на обозначаваната ситуация (token), т. е. на глаголната предикация се приписва определена референция (специфична или неспецифична). В подобни въпроси глаголът от несвършен вид може да се замени с глагол от свършен вид: Kmo написал адрес на конверте? [6, c. 132]. Във втория тип въпроси, които не се отнасят до конкретни, актуализирани действия, напротив, се пита принципно за съществуването на някакъв опит: Kто уже жогда-нибудь терял свой nacnopm? [6, с. 145]. Те са възможни не само с пределни, но и с моментални глаголи (achievements според терминологията на Вендлер [20]), характеризират се с неопределена референция на глаголната предикация и съответстват на (типа) на обозначаваната ситуация (type). Свършеният вид на глагола в подобни въпроси е невъзможен [6, с. 148].

В българския език наред с въпроса за избора на вида възниква въпросът и за избор на времева форма - перфект или аорист. Във връзка с това се запитахме дали семантиката на конкретното граматично време (заедно с акционалната и чисто видова характеристика на глаголите) влияе на реализацията на значенията на $\mathrm{HCB}$, в това число и на общофактическото и неговите подвидове, и ако влияе, то по какъв начин. Освен това при анализа на избора на видо-времева форма в койвъпросите в българския език възниква въпросът за ролята на такива именни категории, каквито са референтният статус и определеността на името.

Поставяне на задачите. В статията ще се опитаме да приложим така предложеното разделение на предикациите на (примерен екземпляр) (token) и (общ фокт» (type) по отношение на българския език, за да определим разпределението на видо-времевите форми и техните функции в специалните въпросителни кой-изречения в минало време.

Изложение на основния материал. За целта ще разгледаме случаи, в които е употребен перфект и аорист от НСВ най-вече във въпросите, оформени с въпросителното местоимени кой и с предикати в аорист и перфект - както е в примери (1), (2) и (3):

(1) Кой е писал на Джордж, за да му каже това? Защо му е писал? (БНК)

(2) Кой писа за убийството на Моу Стейн Сләниицето вәв вашия вестник? (БНК)

(3) Кой писа/е писал молбата?

В посочените примери става въпрос за ситуации, в които извършването на действието и възможното наличие на резултат присъстват в общото знание на събеседниците. В някои случаи това общо знание за действието и резултата се извежда от определеността на обекта, както е в пример (3), в други - от по-широк контекст, както е в (1) и (2). Въпросът сам по себе си цели да изясни кой е извършил действието или какви са другите обстоятелства на ситуацията.

Въпросът, оформен с пълнозначна въпросителна дума, може да се отнася също и до времето (4), мястото или причината (5) за действие, за което само се предполага, че може да е било извършено в определен, конкретен период в миналото. Така например въпросът за времето на осъществяване на действието, изразен с перфект от НСВ, въпреки че формално остава въпрос за (получения опит), всъщност може да изразява съмнение и изненада по повод извършване на действието:

(4) Кога сте ми каввали такова нещо? Ax, да, вярно,казвахте. Аз сзвсем бях забравил. (БНК)

(5) Кой е писал на Джордж, за да му каже това? Защо му е писал? (БНК)

1 * Поднасям искрената си благодарност на Х. Р. Мелиг, който изказа редица ценни съображения в предварителния вариант на статията. Отговорността за възможните грешки и недоглеждания, естествено, е изцяло моя.

Примерът е на X. Р. Мелиг [6, с. 136]. Голямата част от използваните в статията примери са взети от Българския национален корпус (БНК), което специално се посочва след всеки пример. В случаите, когато ко няма указание на източника, примерът е конструиран от нас. 
Що се отнася до аориста от НСВ, ситуацията е малко по-различна: става въпрос за известно и на двамата събеседници действие (6), което може и да е било обсъждано предварително, но за което говорещият иска да уточни някои (забравени?) факти или данни, срв.:

(6) Вие кога се качвахте до езерата? Кой месец е по-подходящ - май или юни? [http://m.bgmamma.com/ index.php?topic $=360791.20]$.

Често въпросът, зададен с глагол от НСВ както в перфект (7), така и в аорист (8), може да изразява критична оценка на действието:

(7) Кой е писал това? [...] Бглвоч и лигоч. Няма драматична съгласуваност. Липсва мотиваичия и форма. (БНК)

(8) Кой писа сутрешната уводна статия? Исусе Христе, хубаво сте я наредили! Кой глупак можа даго напише така?(БНК)

Такива примери дават основание на В. Станков да отбележи фокта, че употребата на НCB в общофактическо значение позволява на говорещия да изрази отрицателното си отношение към действието [14, с. 106], включително и във въпросите за причина и цел на действието: “във въпросителни изречения при насоченост на въпроса към причината за действието или неговата цел чрез употребата на несвършен вид говорещият изразява отсянка на неодобрение на действието, тъй като го смята за ненужно и нецелесъобразно ") [13, с. 76].

Както се вижда от посочените по-горе примери, не са редки случаите на конкуренция на видо-времевите форми, т. е. на субективен избор на несвършен перфект и аорист както при формулирането на неутрален въпрос, така и в контекста на критична забележка.

С цел да проверим предпочитанията на носителите на българския език, в хода на малък лингвистичен експеримент подобни примери бяха предложени на студенти от Софийския университет. От няколко кой-въпроса, отнасящи се до конкретни, актуализирани действия, както е в ситуация (9), и по-долу в (12) и (13), респондентите трябваше да отбележат възможните (по-вероятни и по-малко вероятни), а също така абсолютно невъзможните във всеки отделен случай въпроси.

Първата ситуация ${ }^{1}$ е представена по следния начин: (9) Виера раздадох анкети на няколко колеги. Днес искам да ги събера и питам:

(9a) Кой попълва вчерашната анкета?

(9b) Кой е попълвал виерашната анкета?

(9c) Кой попълни вчерашната анкета?

(9d) Кой е попълнил вчерашната анкета?

Резултатът от анкетата показа, че в ситуация (9) абсолютното мнозинство от предпочитанията на респондентите е на страната на СВ - както в аорист, така и в перфект (съответно варианти (9c) и $(9 \mathrm{~d}))$. Изборът им може да бъде обяснен с наличието на конкретната задача, която е дадена на попълващите, и с фокусирането на вниманието върху резултата, който е налице още в описанието на ситуацията (искам да ги събера). Но въпреки че при представянето на ситуацията беше обърнато специално внимание на това, че резултатът от попълването на анкетата е важен, много от респондентите са сметнали за възможен и отговор с глагол от НСВ, като предпочитанията са на страната на перфекта от НCB (9b) - 68 \%, което може да се обясни с граматичната семантика на перфекта, изразяваща актуалността на резултата от минало действие към момента на речта. Аористът от НСВ (9a) е посочен като най-вероятна от всички възможни форми само от четирима респонденти. Въпреки че процентът на абсолютно предпочитане е малък, почти половината от респондентите смятат тази форма за възможна (макар и малко вероятна).

Тази опция се потвърждава и от следните примери:

(10) А кой оправя после бъркотията? Поличията. (БНК)

а също и:

(11) Ажо ти се ходи до Добрич, да ти кажа кой оправя моята таратайка... (http://www. renaultbg.com/smf/index.php?topic=29769.5;wap2)

Ситуация (12) е основа за изразяване на субективната оценка на говорещия. Представени са четири варианти на въпроса, както в CB, така и в НCB:

(12) На масата виждам попвлнена анкета и питам:

(12а) - Кой попьлва тази анкета? Ила грешки!

(12b) - Кой е попълвал тази анкета? Ила грешки!

(12c) - Кой я попълни тази анкета? Ила грешки!

(12d) - Ћой я е попълнил тази анкета? Ила грешки!

Повече от половината респонденти (59 \%) смятат за най-вероятен варианта с несвършен перфект $(12 \mathrm{~b})$, а $13 \%$ го определят като абсолютно невъзможен. Тук, както и в ситуация (9), става въпрос за конкретно действие и определен обект. По-големият брой предпочитания в тази ситуация на вариант (12b) може да се обясни с прагматични фактори, а именно с желанието на питащия да изрази пред събеседника критичното си отношение към това как е било изпълнено действието

1 Въпросите в примери (6) и (7) са взети от труда на Х. Р. Мелиг [6], преведени са от нас на български и са “вградени) в конкретни комуникативни ситуации. Описанието на ситуациите е дадено на български език. 
(подчертава се, че написаният адрес в анкетата е непълен). Такава възможност дава НСВ, тъй като пределният глагол от НСВ позволява вниманието да се фокусира върху средната фаза на действието, т.е. върху самия процес на изпълнение на действието. Но ако вземем предвид, че въпрос (12а), въпреки че е с предикат от НCB, е получил абсолютно предпочитание само 32 \% (при абсолютна невъзможност, определена от същите респонденти, 29 \%), проблемът, вероятно, е не само във вида на глагола, но и във времевата форма. Затова можем да кажем, че за изразяването на негативна оценка на ситуацията спомага не НСВ на глагола сам по себе си, а съчетанието му с формата на перфекта. Вариантът със свършен аорист (12c) е признат като най-вероятен от 39 \%, а за възможен от 42 \% от респондентите. Въпросът, изразен с формата на свършен перфект е оценен като невъзможен от най-голям брой респонденти (45\%). Ако сумираме отговорите за най-вероятен и по-малко вероятен, но възможен вариант, ще получим следната картина: несвършен перфект 88 \%, свършен аорист $81 \%$, несвършен аорист 71 \%, свършен перфект $55 \%$.

За формулировката на въпроса в пример (13) Много ми харесва прическата на моята позната, искам да разбера кой я е подстригал толкова хубаво предложихме три варианта за продължение на диалога: с несвършен аорист (13a), със свършен перфект (13b) и със свършен аорист (13c):

(13а) - Много хубаво са те подстригали!

- Благодаря.

- Кой те подстригва?

(13b) - Много хубаво са те подстригали!

- Благодаря.

- Койте е подстригал?

(13с) - Много хубаво са те подстригали!

- Благодаря.

\section{- Кой те подстрига?}

При попълване на анкетата по-малко от една трета от респондентите са сметнали вариант (13a) с несвършен аорист за предпочитан, макар и половината от всички анкетирани да го посочват като (възможен). Въпросът, зададен с аорист от СВ (13c) е избран от 84 \% от анкетираните и още 6 \% го признават като възможен. Този фокт може да се обясни на първо място с наличието на конкретен, видим резултат, а на второ - с липсата на отрицателен оценъчен компонент. И наистина, в диалога присъства положителна оценка на резултата (началният комплимент), която показва, че в случая за говорещия е важен не толкова фактът на действието, колкото качеството на резултата, затова и избират свършения аорист. Интересно е обаче това, че вариантът на въпроса с перфект от СВ (13b) в ситуация на положителна оценка на резултата от действието е признат за най-предпочитан само от 19 \% от анкетираните. Нека напомним, че в ситуация (12) при негативна оценка на действието беше избран именно перфектът от НCB, а в предложената ситуация (13) при очевидна положителна оценка на резултата от действието изборът на перфекта от СВ е затруднен. При това в контекста на критична оценка свършеният перфект е напълно възможен - вж. пример (14):

(14) -...знаеш ли какво жи каза?

- Kiakвo?

-Чадо мое кой те е подстригал така идиотски?!

Анализът на посочените примери ни навежда на мисълта за ролята на перфекта като цяло (както от НСВ, така и от (B) при предаването на определено емоционално състояние, в нашия случай недоволство. С други думи, при негативна оценка на начина на протичане на действието или на резултата му говорещият може да избере не само несвършен, но и свършен перфект.

И така, след като съпоставихме разгледаните по-горе примери, можем да кажем, че ги обединява конкретността на ситуацията, която отразяват и наличието на резултат (изразен с определен обект при преходните глаголи). Основните различия, които определят избора на най-предпочитаната форма, са в областта на комбиниране на значенията на вида и времето с тяхната прагматична натовареност. Така например перфектът в конкретна ситуация (както от НСВ, така и от СВ) може да имплицира критична оценка на действието, докато аористът от СВ обикновено назовава действия, оценявани неутрално или положително. С най-неустойчива позиция при въпросите с местоимение жой се отличава аористът от НCB. ${ }^{2}$ Може да се предположи, че конкуренцията свършен аорист несвършен аорист в ситуацията на жой-въпрос за конкретно действие се решава в полза на СВ (макар че като допустим се признава и аористът от НСВ на пределните глаголи). Казаното се отнася преди всичко до пределните глаголи от НСВ - те се използват във въпросите с жой както в пер-

\footnotetext{
txt.

${ }^{1}$ https://archive.org/stream/PlayboyBulgariaNovember2009/Playboy_Bulgaria_November_2009_djvu.

${ }^{2}$ В другите типове изказвания (съобщителни изречения и $\partial а /$ н-въпроси) мисълта на Ю. С. Маслов, че “обобщено-фактическото значение трябва да се разглежда като най-важното значение на несвършения аорист» [5, с. 268269 ] си остава в сила, макар и с известни уговорки. Ще отбележим само, че в труда на Ю. С. Маслов [5] се използват примери от българската литература от XIX век, много от които днес звучат странно. Срв. също коментара на Р. Ницолова към известния пример на Ю. С. Маслов: “Ето един пример, днес схващан като архаичен, приведен от Маслов: Марийка кәсно ли те намери? - Коя Марийка? - Kаж? Не намира̀ ли те тя?» [8, с. 291].
} 
фект, така и в аорист. Употребата в същите контексти на моментални глаголи предполага известни ограничения: несвършеният аорист от моменталните глаголи в конкретна ситуация, включително и в жой-въпросите (примери (15), (16) и (17)), се измества от свършен:

(15) Кой ?реща / срещна Иван?

(16) Кой * намира /намери манатарки миналата година?

(17) Кой ? ивхвърля / изхвърли боклука?

Допускаме, че въпрос (17) с аорист от НСВ (Кой изжвғрля божлука?) е возможен, ако говорещият предполага, че в кофата за боклук може да са попаднали някакви ценни вещи и търси човек, който може да му изясни ситуацията.

Независимо от това, макар и рядко, в друг тип въпроси, например, можем да срещнем примери за употреба на несвършен аорист от моменталните глаголи. В тази връзка показателен е диалог (18), в който питащият се интересува дали се е случила ситуацията 'среща', т.е. реализирал ли се е фоктът на срещата (в дадения случай непреднамерена) на двамата участници в ситуацията.

(18) -Onи, среща ${ }^{\text {нсв-аор } л и ~ д н е с ~ М и л к о ? ~}$

Опи изтргпна:

-Да.[...]-Видях го тази вечер, срещнах го на улииата, но той не ме забеляза. (Г. Райчев, Съновидения)

Употребата на перфект от НСВ в екзистенциално значение няма ограничения - във въпросите с несвършен перфект се срещат не само пределни (19), но и моментални ((20) и (21)) глаголи:

(19) Кой е правил записите на телебонните разговори? ${ }^{1}$

(20) Кой е казвал подобно нешо? ${ }^{2}$

(21) Но кой е срещал някога таквв човек? И кой е срещал човек, роден на седмия ден от седмия месеи на седемстотин седемдесет и седмата година? (БНК)

Всички действия в предложените по-горе въпроси се характеризират с неопределена рефференция на глаголната предикация (type), не са свързани с определен момент в миналото и се отнасят към екзистенциалния подтип на общофактическото значение на НСB, затова въпросът за миналия опит или просто за съществуването на действието в миналото може да се формулира с помощта на несвършени глаголи от всички семантични класове. Въпросите с пределни глаголи от НСВ предполагат наличието на неопределителното наречие някога, докато във въпросите с моментални глаголи неопределеността на момента на действието се имплицира. С други думи, точно липсата на процесуално значение при моменталните глаголи от $\mathrm{HCB}$, тяхната неопределена кратност заедно с времевата нелокализираност на действието изразява екзистенциалната семантика на изказванията.

Нека разгледаме сега някои ограничения, свързани с аргументите на предиката, тъй като именно във въпросите с пълнозначни въпросителни думи в българския език ярко се проявява ролята на рефферентността на името. В примерите с аорист и перфект от НСВ глаголи, назоваващи пределен процес, определеният обект във въпросите с жой е възможен както в единствено, така и в множествено число. При това за конкретността и известността на ситуацията сигнализира преди всичко определеността на обекта (граматически изразена с определителен член), а перфектът и аористът от НСВ могат да се конкурират (22):

(22) Кой писа/е писал пислото / писмата?

Във въпросите с жой е възможен и нереферентен обект. Така например неопределеният обект с нулев член е възможен ${ }^{3}$ дори ако ситуацията предполага, че е реализирано конкретно действие. В подобни случаи именната група обикновено е съпроводена от определение (или то може да се подразбира), а предикатът е изразен с аорист от НСВ: въпрос (23) задаваме, ако писането на заявления до ректора вече е обсъждано от група хора и сега се уточнява точно кой от възможните субекти е извършил такова действие: ${ }^{4}$

(23) Кой писа молба до Режтора?

Нереферентният обект във въпросите с кой обаче най-добре спомага за изразяване на екзистенциалното общофактическо значение на несвършения перфект, тъй като в тях се пита дали субектът на действието притежава определен опит (знания или умения), получен в миналото, без да се посочва конкретният момент и обект (възможен) на извършване на действието (срв. примери (24) и (25)):

(24) Кой е строил каши?

(25) Кой е писал молби до Режтора (и знае как се пишат)?

Подобни въпроси дават възможност на субекта да бъде приписана определена характеристика, която е резултат от получен в миналото опит. Към общофрактическия статус на такава предикация насочва именно нереферентният обект, назоваващ клас от предмети, изразен с форма за множествено число и нулев член. При експлицитно изразено (или подразбирано) неопределително наречие

\footnotetext{
${ }^{1}$ http://www.vesti.bg/bulgaria/obshtestvo/prokuraturata-koj-e-pravil-zapisite-3522631

2 http://bg.checkonline4you.com/kak-da-se-nauchim-da-ne-se-obizhdame/

${ }^{3}$ В нашата разработка приемаме концепцията на българските лингвисти, че в български съществуват нулев показател за нереферентността на именната група (т. нар. нулев член) и неопределителен член един, обозначаващ специфичната неопределеност на именната група, нейната едностранна идентифицираност [15, с. 150-151, 8, с. 79].

${ }^{4}$ Благодаря на колежката Л. Ласкова за това ценно наблюдение.
} 
някога (26), а също и при наличието на конкретизиращо определение (27) е възможен и нереферентен обект в единствено число:

(26) Кой е писал (някога) молба до Ректора?

(27) Койе строил двуетажна къща?

Обектът с неопределителен член един в кой-въпросите трябва да бъде изследван отделно. За момента можем да кажем, че в конкретна ситуация, изразена с несвършен аорист от пределен глагол, експлицитно изразената (с помощта на един) невъзможност за слушащия да идентифицира обекта изключва употребата на такава форма, каквато е аористът (28):

(28) * Кой писа една молба / едни молби?

Употребата на обект с неопределителен член един е затруднена и при въпросите с несвършен перфект (29):

(29) ? К Кой е строил една кәща /едни къщи?

Тази особеност според нас е свързана с това, че идентифицираността на обекта, макар и едностранна (употреба на един, липса на нулев определителен член), явно не позволява на несвършения перфект да изразява екзистенциално общофрактическо значение, а пък слабата определеност на обекта (липса на определителен член или друг спецификатор) не го премества в категорията на конкретно-референтното (акционалното) значение (за което, да напомним, се изисква определен обект).

Изводи. И така, проведеният от нас анализ показа, че в кой-въпросите с несвършен аорист в българския език се изразява акционалното значение на НСВ при условие, че става въпрос за пределен глагол, назоваващ контролируемо от субекта действие, което предполага определен обект. C несвършен аорист е възможен и неопределен обект (с нулев член, но и с несъгласувано определение или подчинено изречение, което стеснява класа на имената, можещи да изпълняват функцията на пряк обект). В последния случай действието, за което се задава въпрос в аорист, трябва да се предполага (или да е очаквано) от говорещия в тази ситуация. Несвършеният перфект на глагола с определен обект също може да изразява акционалния подвид на общофактическото значение, при това е допустимо емоционално, критично отношение към извършването на действието. И в двата случая става въпрос за (екземпляр) (token) на ситуацията, а глаголът от несвършен вид може да бъде заменен с глагол от свършен вид. Основните случаи на употреба на несвършен перфект обаче се отнасят до неактуалните, нелокализирани във времето ситуации, отразяващи минал опит на субекта, което ни позволява да ги отнесем към екзистенциалния подтип на общофактическото значение. Точно поради това за изразяване на обекта се използват нереферентни именни групи (с нулев член), възможно е и наличието на неопределеното наречие някога. В подобни въпроси глаголът от несвършен вид не може да бъде заменен с глагол от свършен вид; смятаме, че те напълно изразяват определен (тип) (

Специфочино неопределената именна група с неопределителния член един в жой-въпросите с несвършен аорист явно е несъвместима с интенцията за изясняване на субекта на неизвестно за слушащия (макар и конкретно) действие, което се разпространява върху неизвестен за него обект. Употребата на обекта с неопределителен член един е затруднена и в кой-въпросите с несвършен перфект: едностранната идентификация на обекта затруднява изразяването на екзистенциалния подтип на общофактическото значение, докато недостатъчната определеност на обекта не ни позволява да говорим за акционално значение на несвършения вид.

\section{Литература}

1. Андрейиин Л. Към характеристиката на перфекта (минало неопределено време) в българския език // Помагало по българска морфология. София : Наука и изкуство, 1976. С. 277-286.

2. Андрейчин Л. Основна българска граматика. София : Хемус, 1944. 560 с.

3. Български национален корпус. URL : http://search.dcl.bas.bg/

4. Гловинская M. Я. Многозначность и синонимия в видо-временной системе русского глагола. М. : Азбуковник, 2001. $319 \mathrm{c}$.

5. Маслов Ю. С. Глагольный вид в современном болгарском литературном языке // Вопросы грамматики болгарского литературного языка. М. : Изд-во АН СССР, 1959. С. 157-312.

6. Мелиг X. Р. Вид и референциальный статус глагольной предикации в тексте. Употребление видов в вопросах с местоимением жто // Основные проблемы русской аспектологии. СПб. : Наука, 2002. С. 128-150.

7. Мелиг $X . P$. Общефактическое и единично-фактическое значения несовершенного вида в русском языке // Вестник Московского университета. Сер. 9. Филология. 2013. № 4. С. 19-46.

8. Ничолова Р. Българска граматика. Морфология. София : Университетско изд-во “Св. Климент Охридски», 2008. $523 \mathrm{c}$.

9. Падучева $E . B$. К семантике несовершенного вида в русском языке : общефактическое и акциональное значение // Вопросы языкознания. 1991. № 6. С. 34-45.

10. Падучева $E . B$. Семантические исследования. М.: Школа “Языки русской культуры», 1996. 464 с.

11. Падучева E. B. Русский имперфектив : инвариант и частные значения // Встник Московского университета. Сер. 9. Филология. 2013. № 4. С. 7-18.

12. Пенчев Й. Бележки върху многократните к-думи // Българският език през ХХ век. София : Академично издво “Проф. Марин Дринов", 2001. С. 75-77. 
13. Станков B. Конкуренцията на глаголните видове в българския книжовен език. София : Издателство на Българската академия на науките, 1976. $131 \mathrm{c.}$

14. Станков В. Стилистични особености на българския глагол. София, 1981. 134 с.

15. Станков $B$. За една семантична особеност на категорията определеност / неопределеност на имената в българския език // Български език. 1995. Vol. 45. № 1/2. C. 148-151.

16. Шатуновский И. Б. Проблемы русского вида. М. : Языки русской культуры, 2009. 352 с.

17. Dickey S. M. A Comparative Analysis of the Slavic Imperfective General-Factual // Journal of Slavic Linguistics. 1995. Vol. 3. No. 2. P. 288-307.

18. Dickey S. M. Parameters of Slavic Aspect. A Cognitive Approach. Stanford : Center for the Study of Language and Information, 2000. $316 \mathrm{c}$.

19. Mehlig H. R. Verbal Aspect and the referential Status of verbal Predicates : On Aspect Usage in Russian Who-Questions // Journal of Slavic Linguistics. 2001. Vol. 9. No. 1. P. 99-125.

20. Vendler Z. Verbs and Times // Philosophical Review. 1957. Issue 66. P. 143-160.

\section{References}

1. Andreychin, L. (1976), "On the characteristics of the perfect (indefinite past) in Bulgarian», Sourcebook of Bulgarian morphology ["Kam kharakteristikata na perfekta (minalo neopredeleno vreme) v balgarskiya ezik», Pomagalo po balgarska morfologiya], Nauka i izkustvo, Sofia, pp. 277-286.

2. Andreychin, L. (1944), Fundamental Bulgarian grammar [Osnovna balgarska gramatika], Hemus, Sofia, 560 p.

3. Bulgarian national Corpus [Balgarski natsionalen korpus], URL : http://search.dcl.bas.bg/.

4. Glovinskaya, M. Ya. (1982), Polysemy and synonymy in the aspect-tense system of the Russian verb [Mnogoznachnost' $i$ sinonimiya v vido-vremennoy sisteme russkogo glagola], Azbukovnik, Moscow, 319 p.

5. Maslov, Ju. S. (1959), "Verbal Aspect in the Contemporary Bulgarian Literary Language», Questions of Grammar of the Bulgarian Literary Language ["Glagol'nyi vid v sovremennom bolgarskom literaturnom yazyke», Voprosy grammatiki bolgarskogo literaturnogo iazyka], Publishing House of the Academy of Sciences of USSR, Moscow, pp. 157-312.

6. Mehlig, H. R. (2002), "Aspect and the referential status of the verbal predication in the text. Using of the aspects in the interrogative sentences with the pronoun kto [who]" Main issues of Russian aspectology, ["Vid i referencial'nyj status glagol'noj predikacii v tekste. Upotreblenie vidov v voprosah s mestoimeniem kto", Osnovnye problemy russkoi aspektologii], Nauka, St. Petersburg, pp. 128-150.

7. Mehlig, H. R. (2013), "General-factual and singular-factual meanings of imperfective aspect in in Russian", Moscow University Bulletin, ser. 9, Philology [ (Obshchefakticheskoe i edinichno-fakticheskoe znacheniya nesovershennogo vida v russkom yazyke», Vestnik Moskovskogo univetsiteta, Ser. 9, Filologiya], Moscow Lomonosov State Univ., Moscow, No. 4, pp. $19-46$.

8. Nitsolova, R. (2008), Bulgarian Grammar. Morphology [Balgarska gramatika. Morfologiya], St. Kliment Okhridski Publ., Sofia, 523 p.

9. Paducheva, E. V. (1991), "On the Semantics of the Imperfective Aspect in the Russian Language : General- Factual and Actional Meanings», Topics in the study of language [ [ $\mathrm{K}$ semantike nesovershennogo vida v russkom yazyke : obshchefakticheskoe i aktsional'noe znachenie», Voprosy yazykoznaniya], Moscow, Vol. 6, pp. 34-45.

10. Paducheva, E. V. (1996), Semantic Studies [Semanticheskie issledovaniya], Shkola "Jazyki russkoy kul'tury", Moscow, $464 \mathrm{p}$.

11. Paducheva, E. V. (2013), „Russian imperfective : invariant and particular meanings, Moscow University Bulletin, ser. 9, Philology, 2013, № 4, [ "Russkij imperfektiv: invariant i chastnye znacheniya», Vestnik Moskovskogo univetsiteta, Ser. 9, Filologiya], Moscow Lomonosov State Univ., Moscow, No. 4, pp. 7-18.

12. Pejchev, J. (2001), "Notes on the multiple wh-words», Bulgarian in the XX century, [Belezhki varhu mnogokratnite k-dumi, Balgarskiyat ezik prez XX vek], Academic Publ. "Prof. Marin Drinov", Sofia, pp. 75-77.

13. Stankov, V. (1976), Competition between Verbal Aspects in the Bulgarian Literary Language [Konkurentsijata na glagolnite vidove $v$ balgarskija knizhoven ezik], Bulgarian Academy of Sciences Publ., Sofia, $131 \mathrm{p}$.

14. Stankov, V. (1981), Stylistic properties of Bulgarian verbs [Stilistichni osobenosti na balgarskija glagol], Narodna prosveta, Sofia, $134 \mathrm{p}$.

15. Stankov, V. (1995), "On a semantic feature of the category definiteness / indefiniteness of the names in Bulgarian", Bulgarian language, Sofia, Vol. 45, No. 1/2, pp. 148-151.

16. Shatunovskiy, I. B. (2009), Problems of the Russian aspect [Problemy russkogo vida], Jazyki russkoy kul'tury, Moscow, $352 \mathrm{p}$.

17. Dickey, S. M. (1995), A Comparative Analysis of the Slavic Imperfective General-Factual., Journal of Slavic Linguistics, Vol. 3, No. 2, pp. 288-307.

18. Dickey, S. M. (2000), Parameters of Slavic Aspect. A Cognitive Approach, Center for the Study of Language and Information, Stanford, $316 \mathrm{p}$.

19. Mehlig, H. R. (2001), Verbal Aspect and the referential Status of verbal Predicates : On Aspect Usage in Russian Who-Questions, Journal of Slavic Linguistics, Vol. 9, No. 1, pp. 99-125.

20. Vendler, Z. (1957), Verbs and Times, Philosophical Review, 1957, Issue 66, pp. 143-160. 


\section{СЛАВКОВА Светлана}

кандидат педагогических наук, доцент кафедры русского языка и литературы при департаменте устного

и письменного перевода Болонского университета, Кампус Форли; Corso della Repubblica, 136, 47121 Forlì, Italia, тел.: +39 (349) 3747948; e-mail: svetlana.slavkova@unibo.it; ORCID ID: 0000-0001-5900-6616;

SCOPUS ID: 56466016; РИНЦ Autor ID: 437711.

\section{КТО-ВОПРОСЫ В БОЛГАРСКОМ ЯЗЫКЕ С ТОЧКИ ЗРЕНИЯ РЕАЛИЗАЦИИ В НИХ ОБЩЕФАКТИЧЕСКОГО ЗНАЧЕНИЯ НЕСОВЕРІЕННОГО ВИДА}

Аннотация. Целью предлагаемой работы является анализ употребления несовершенного вида глаголов в рамках тематики изучения общефактического значения HCВ. Объект анализа - частный вопрос с местоимением жой в болгарском языке. Предмет анализа - критерии выбора видо-временной формы - презенса, перфекта и аориста глаголов несовершенного и совершенного видов. Исследуется влияние семантики конкретного грамматического времени (наряду с акциональной и собственно видовой характеристикой глаголов) на реализацию значений НСB, в том числе общефактического и его подвидов. Кроме того, при анализе выбора видо-временной формы в специальном вопросе в болгарском языке возникает проблема роли именных категорий. Результат проведённого нами анализа показал, что общефактическое значение реализуется на уровне высказывания и что, помимо вида глагола, необходимо учитывать грамматическое время и такие именные категории, как референтный статус и определённость имени. На данный момент можно сделать вывод о том, что несовершенный аорист в болгарском языке выражает акциональное значение HCB предельных глаголов с определённым объектом. Неопределённый объект возможен, если действие, о котором задан вопрос в форме аориста, предполагается или ожидается говорящим. Несовершенный перфект глагола с определённым объектом тоже может выражать акциональный подвид общефактического значения; при этом допускается эмоциональное критическое отношение к совершению действия. В обоих случаях глагол несовершенного вида можно заменить глаголом совершенного вида. Однако основные случаи употребления несовершенного перфекта касаются неактуальных, нелокализованных во времени ситуаций, отражающих прошлый опыт субъекта, что позволяет отнести их к экзистенциальному подтипу общефактического значения. Поэтому и для выражения объекта используются нереферентные именные группы (с нулевым артиклем), возможно также наличие неопределённого наречия някога. В таких вопросах глагол несовершенного вида нельзя заменить глаголом совершенного вида.

\section{Svetlana SLAVKOVA,}

$\mathrm{PhD}$, associate professor of Russian language and linguistics, Department for interpretation and translation, Bologna university, Campus of Forlì (Italy); Corso della Repubblica 136, 47121 Forlì, Italia, tel.: +39 3493747948 ; e-mail: svetlana.slavkova@unibo.it; ORCID ID: 0000-0001-5900-6616; SCOPUS ID: 56466016; РИНЦ Autor ID: 437711/

\section{WHO-QUESTIONS FROM THE POINT OF VIEW OF IMPLEMENTATION OF THE GENERAL-FACTUAL MEANING OF IMPERFECTIVE VERBS IN THE BULGARIAN LANGUAGE}

Summary. The purpose of the present papers is to analyze the general-factual meaning of the imperfective verbs. The subject of this study are specific $k o j$ [who]-questions in Bulgarian. The object of analysis are criteria of the selection of the tense-aspectual forms of verbs, i.e. present tense, aorist, perfect tense of the imperfective and perfective verbs. In this paper, semantic and grammatical analysis methods are used. The author studies how aspect and tense interact to determine the manifestation of the general-factual meaning of the IPF verbs. In addition, the role of nominal categories, such as definiteness and referential status, is considered. The analysis reveal that the general-factual meaning is realized by means of various components of the utterance and that it is necessary to take into account the functional roles played by tenses and nominal categories as the reference status and definiteness of the name. The results show that the actional meaning of IPF verbs is expressed by imperfective aorist of terminative transitive verbs that control a definite argument. It is also possible to use an imperfective perfect of any kind of verb. In these cases an aspectual concurrence may occur. However, the main cases of imperfect perfect use concern temporally non-localized situations and reflect the past experience of the subject. This use marks an existential subtype of the general factual meaning. This is why the non-referential object occurs and an aspectual concurrence is impossible.

Key words: aspect, general-factual meaning, aorist, perfect, the Bulgarian language.

Статтю отримано 10.09.2018 p. 